\title{
CUPRIC CITRATE AS GROWTH PROMOTER FOR BROILER CHICKENS IN DIFFERENT REARING STAGES
}

\author{
Mônica Maria de Almeida Brainer ${ }^{1}$; José Fernando Machado Menten ${ }^{2 *}$; Marcos Martinez do \\ Vale; Sônia Cristina Daroz de Morais \\ ${ }^{1}$ EAFCe - Depto. de Zootecnia, C.P. 51 - 76300-000 - Ceres, GO - Brasil. \\ ${ }^{2}$ USP/ESALQ - Depto. de Zootecnia, C.P. 9 - 13418-900 - Piracicaba, SP - Brasil. \\ *Corresponding author <jfmmente@esalq.usp.br>
}

\begin{abstract}
Feeding cupric citrate as alternative to cupric sulfate to broilers has been suggested in the literature. Day-old male broiler chicks $(1,200)$ were used in an experiment to evaluate the efficacy of cupric citrate supplementation (75 mg Cu kg${ }^{-1}$ ) during the 1-21, 22-42 or 1-42 d periods in comparison to an unsupplemented diet and a diet supplemented with cupric sulfate (200 mg Cu kg${ }^{-1}, 1-42$ d). A randomized block design was used, with five treatments, six replicates and 40 birds per pen. The diets, based on corn and soybean meal, and water were offered ad libitum during the 42-day experimental period. Over the entire period, there was no effect of copper supplementation $(P>0.05)$ on bird live weight, weight gain, feed intake, feed conversion and mortality. Cupric citrate supplementation on the $22-42 \mathrm{~d}$ period resulted in worse feed conversion as compared to broilers receiving cupric sulfate (2.014 vs. 1.967, $P<0.05)$. Copper residues in the litter were reduced when broilers were fed cupric citrate, as compared to cupric sulfate $(P<0.01)$. The absence of response to copper supplementation can be attributed to the environmental and sanitary rearing conditions.
\end{abstract}

Key words: broiler litter, poultry, copper, performance

\section{CITRATO CÚPRICO COMO PROMOTOR DE CRESCIMENTO DE FRANGOS DE CORTE DIFERENTES EM FASES DE CRIAÇÃO}

\begin{abstract}
RESUMO: Citrato cúprico foi apontado como alternativa ao sulfato cúprico como promotor de crescimento na dieta de frangos. Este trabalho avaliou a eficácia do citrato cúprico em diferentes fases da criação de frangos de corte. Foram utilizados 1200 pintos machos, em um experimento em blocos casualizados, com cinco tratamentos, seis repetições e 40 aves por parcela. Os tratamentos consistiram de uma dieta não suplementada ou suplementada com citrato cúprico anidro $\left(75 \mathrm{mg} \mathrm{Cu} \mathrm{kg}^{-1}\right)$ de 1 a 21 dias, de 22 a 42 dias ou de 1 a 42 dias, ou com sulfato cúprico pentahidratado $\left(200 \mathrm{mg} \mathrm{Cu} \mathrm{kg}^{-1}\right)$ de 1 a 42 dias. Foram avaliados o desempenho das aves e o resíduo de cobre na cama. Dietas, à base de milho e farelo de soja, e água foram fornecidas à vontade durante todo o período experimental. Não houve efeito da suplementação de cobre $(P>0,05)$ sobre o peso vivo, ganho de peso, consumo de ração, conversão alimentar e mortalidade mais refugagem. Os frangos que receberam citrato cúprico na ração a partir dos 22 dias tiveram, no período 22-42 dias, conversão alimentar pior que aqueles que receberam sulfato cúprico ( 2,014 vs. $1,967, P<0,05)$. $\mathrm{O}$ resíduo de cobre na cama das aves que receberam citrato cúprico na dieta foi reduzido em comparação às que receberam sulfato cúprico $(P<0,01)$. $O$ cobre não resultou em efeito promotor de crescimento em função das condições ambientais e sanitárias do experimento.

Palavras-chave: aves, cobre, cama de frango, desempenho
\end{abstract}

\section{INTRODUCTION}

Copper $(\mathrm{Cu})$ is an essential micromineral that can be added to broiler chicken diet at high levels, acting as a growth promoter. Several authors have observed that the addition of levels ranging from 125 to $250 \mathrm{mg} \mathrm{Cu} \mathrm{kg}^{-1}$, as copper sulfate or carbonate, resulted in a positive response in body weight and feed conversion efficiency (Fisher et al., 1973; Hoda \& Maha, 1995). Cu can be added to the diet under several forms as growth stimulant; however, the most utilized is the sulfate form (Rostagno et al., 1994).
The mechanisms by which $\mathrm{Cu}$ promotes performance improvements in poultry and swine are not completely cleared. One of the mechanisms pointed out as responsible for the effects of $\mathrm{Cu}$ in relation to performance improvement would be its action over disease-causing microorganisms that, even without displaying clinical signs, might be detrimental to animal growth (Cromwell, 1991). In this respect, there is evidence that antimicrobial agents are usually more efficient as growth promoters in old facilities or buildings with poor sanitary conditions than in new, isolated environments (Hill et al., 1953; Visek, 1978). 
Stimulation of the immune system results in metabolic alterations known as immunological stress, which decrease the efficiency of nutrient utilization toward weight gain, possibly because of alterations in the absorption of nutrients or in the metabolic rate. The main mediator of these metabolic modifications is interleukin-1 (Klasing et al., 1987). The degree of sanitation in the environment affects the efficacy of antibiotics in promoting growth, since the ability of these additives in improving poultry performance depends on the extent of the microbial challenge (Roura et al., 1992). It has been demonstrated by those authors that, in a clean environment, weight gain and feed conversion in birds supplemented with antibiotics were similar to those that did not receive supplementation in their diet. However, in a poorly sanitized environment, the increase in growth and feed conversion rates attributed to antibiotics was accompanied by a reduction in circulating interleukin levels, which suggests that antibiotics reduce the immunological stress.

Studies carried out by Pesti \& Bakalli (1996) and Ewing et al. (1998) lead to positive results on performance improvement of broiler chicken either with the use of pentahydrate cupric sulfate or anhydrous cupric citrate. However, the latter resulted in bird performance improvement at lower levels ( 63 or $75 \mathrm{mg} \mathrm{Cu} \mathrm{kg}^{-1}$ ) than cupric sulfate (125 or $250 \mathrm{mg} \mathrm{Cu} \mathrm{kg}^{-1}$ ). Lower levels of $\mathrm{Cu}$ residues in the litter were also observed when cupric citrate was utilized, in addition to a more pronounced growth promoting effect at growing-finishing rearing stages as compared to the initial stages.

There is currently great concern with respect to the use of high $\mathrm{Cu}$ levels in broiler chicken feed, because of the residues of this mineral in the litter, which might compromise its commercial value. The value of litter as a source of nutrients for animal feeding and for fertilization has been long acknowledged, and several authors observed that the addition of $\mathrm{Cu}$ sources to broiler chicken feed yields excreta that are potentially toxic to cattle, and to sheep in particular (Ryssen et al., 1977; Banton et al., 1987).

The present study was motivated by the fact that in experiments by Pesti \& Bakalli (1996), an effect of cupric citrate on the performance of broiler chicken was found for the period from 1-42 days, but not in the period from 1-21 days. Therefore, the growth promoter effect was manifested in the age period between 22-42 days. These results are contrary to those observed by other authors who have studied the action of antimicrobial agents at different rearing stages and verified greater growth stimulation in birds fed diets containing antibiotics during the first four weeks of life, with differences disappearing by the end of the experimental period (Fernandez et al., 1973; Marusich et al., 1973; Zuanon, 1995).

The objective of this study was to evaluate cupric citrate effects on the performance of broiler chicken when supplemented at rearing stages from 1 to 21 days,
22 to 42 days and from 1 to 42 days, as compared to cupric sulfate supplementation, and to determine $\mathrm{Cu}$ concentration in broiler chicken litter under these treatments.

\section{MATERIAL AND METHODS}

The experiment was carried out utilizing 1,200 day-old male chicks, line AgRoss, during the period from 1 to 42 days of age. The chicks were divided into homogeneous, 40-bird groups, arranged in thirty, $5.0-\mathrm{m}^{2}$ pens with concrete floor over a $4.0-\mathrm{cm}$ rice hulls bedding. Birds were maintained under constant lighting and received water and feed without restriction.

The base diets utilized during the experimental period (Table 1) were divided into three types, according to the nutritional requirements of the rearing stages: starter ( 1 to 21 days), grower (22 to 35 days) and finisher (36 to 42 days), and were formulated based on corn and soybean meal, following recommendations by Rostagno et al. (1994).

Table 1 - Percentage composition and calculated values for base diets.

\begin{tabular}{|c|c|c|c|}
\hline & \multicolumn{3}{|c|}{ Feed } \\
\hline Ingredient & Starter & Grower & Finisher \\
\hline Corn & 57.32 & 62.45 & 64.82 \\
\hline Soybean meal & 36.53 & 32.05 & 29.43 \\
\hline Soybean Oil & 2.30 & 2.05 & 2.39 \\
\hline Dicalcium Phosphate & 1.95 & 1.74 & 1.75 \\
\hline Limestone & 1.12 & 1.02 & 1.04 \\
\hline DL-Methionine 99\% & 0.16 & 0.12 & 0.11 \\
\hline Common salt & 0.30 & 0.30 & 0.30 \\
\hline Choline Chloride $60 \%$ & 0.08 & 0.04 & 0.02 \\
\hline Vitamin Supplement ${ }^{\mathrm{a}}$ & 0.12 & 0.10 & 0.08 \\
\hline Mineral Supplement ${ }^{\mathrm{b}}$ & 0.06 & 0.06 & 0.06 \\
\hline Anticoccidial Agent & $0.05^{\mathrm{c}}$ & $0.06^{\mathrm{d}}$ & - \\
\hline \multicolumn{4}{|c|}{ Calculated Composition } \\
\hline Crude Protein, $\%$ & 21.6 & 20.0 & 19.0 \\
\hline Methionine, $\%$ & 0.49 & 0.44 & 0.41 \\
\hline Meth + Cystine, $\%$ & 0.85 & 0.77 & 0.73 \\
\hline Lysine, \% & 1.10 & 0.99 & 0.93 \\
\hline Calcium, \% & 1.00 & 0.90 & 0.90 \\
\hline Available Phosphorus, \% & 0.45 & 0.41 & 0.41 \\
\hline Metabolizable Energy, $\mathrm{kcal} \mathrm{kg}^{-1}$ & 3,000 & 3,050 & 3,100 \\
\hline
\end{tabular}

${ }^{\mathrm{a}} \mathrm{Each} \mathrm{kg}$ of the vitamin premix contains: vit. A 10,000,000 UI; vit. $\mathrm{D}_{3}$ 2,000,000 UI; vit. E 30,000 mg; vit. $\mathrm{K}_{3} 3,000 \mathrm{mg}$; vit. $\mathrm{B}_{1} 2,000$ mg; vit. $B_{2} 6,000 \mathrm{mg}$; vit. $B_{6} 4,000 \mathrm{mg}$; vit. $B_{12} 15,000 \mathrm{mcg}$; folic acid 1,000 mg; pantothenic acid $12,000 \mathrm{mg}$; nicotinic acid 50,000 mg:

${ }^{\text {bEach }} \mathrm{kg}$ of the mineral premix contains: Mn 16,000 mg; $\mathrm{Cu} 20,000$ mg; Zn 100,000 mg; Fe 100,000 mg; I 2,000 mg; Se 250 mg.

${ }^{\mathrm{c}}$ Anticoccidial utilized: maduramicin $0.75 \%+$ nicarbazin $8.0 \%$.

${ }^{\mathrm{d} A n t i c o c c i d i a l}$ utilized: lasalocid sodium $15 \%$. 
At the end of the experiment, litter samples were collected from all pens for $\mathrm{Cu}$ residue analysis by atomic absorption spectrophotometry; a sample of the rice hulls utilized as bedding substrate was also analyzed. During the experimental phase, no moist portions of the litter were removed, and a fine layer of dry bedding was added under and around the water troughs as needed. Water samples were collected from the troughs for $\mathrm{Cu}$ residue analysis, and only traces of $\mathrm{Cu}$ were detected (less than $0.05 \mathrm{mg} \mathrm{kg}^{-1}$ ).

The experimental design was set up as randomized blocks, with five treatments, six replicates and 40 birds per pen. The replicates corresponded to blocks, which were created based on insolation and temperature differences in the facilities.

Supplementations of $75 \mathrm{mg} \mathrm{Cu} \mathrm{kg}{ }^{-1}$ in the form of anhydrous cupric citrate $\left(\mathrm{C}_{6} \mathrm{H}_{4} \mathrm{Cu}_{2} \mathrm{O}_{7}\right)$ in the diet were tested as a growth promoter, at different rearing stages. Therefore, treatments corresponded to a base diet not supplemented with any antimicrobial agent (Control), base diet + cupric citrate from 1 to 21 days, followed by the base diet (Citrate 1-21), base diet + cupric citrate from 22 to 42 days, preceded by the base diet (Citrate 22-42), base diet + cupric citrate from 1 to 42 days (Citrate 142) and base diet $+200 \mathrm{mg} \mathrm{Cu} \mathrm{kg}^{-1}$ in the form of cupric sulfate pentahydrate from 1 to 42 days (Sulfate). $\mathrm{Cu}$ concentrations in the products were $37.4 \%$ for the cupric citrate and $25.0 \%$ for the cupric sulfate.

The variables analyzed over 1 to 21 days, 22 to 42 days and from 1 to 42 days were: weight gain (WG), feed intake (FI), feed conversion efficiency ( $\mathrm{kg}$ of feed consumed per kg weight gain, FC), mortality + culling (MORT) and $\mathrm{Cu}$ residues in litter (RES). Live weight (LW) at 21 and 42 days was also analyzed. In all periods, MORT data were transformed according to arc sin $(\% / 100)^{1 / 2}$. Data were analyzed with the GLM SAS (1990) procedure and means compared by the Tukey test $(P=$ $0.05)$.

\section{RESULTS AND DISCUSSION}

There was no difference $(P>0.05)$ between treatment means for LW at 21 days and WG, FI, FC and MORT during the period of 1 to 21 days (Table 2). There was no difference $(P>0.05)$ between treatment means for WG, FI, and MORT during the period of 22 to 42 days (Table 3). However, when anhydrous cupric citrate was utilized during the period from 22 to 42 days in the diet of birds that had not received any supplementation previously (Citrate 22-42 treatment), FC was poorer than for birds of the Sulfate treatment $(P<0.05)$. There was no difference $(P>0.05)$ between treatments for LW at 42 days and for WG, FI, FC and MORT from 1 to 42 days, i.e., none of the $\mathrm{Cu}$ sources provided a growth promoting effect (Table 4).
Even though some authors (Fisher et al., 1973; Hoda \& Maha, 1995) verified that adding high levels of several $\mathrm{Cu}$ sources to the diet (from 125 to $160 \mathrm{mg} \mathrm{kg}^{-1}$ ) of broiler chicken improved performance, in a different paper (Poupoulis \& Jensen, 1976) the utilization of 250 $\mathrm{mg} \mathrm{Cu} \mathrm{kg}{ }^{-1}$ in the broiler chicken diet did not improve growth and feed conversion, and there was no difference in the response to $\mathrm{Cu}$ supplementation in the initial or final rearing periods.

Table 2 - Effects of dietary cupric citrate and cupric sulfate pentahydrate on performance of broiler chicken at age between 1 and 21 days.

\begin{tabular}{lccccc}
\hline Treatment & LW 21 d & WG & FI & FC & MORT \\
\hline Control & 0.77 & 0.73 & 1.16 & 1.591 & 1.30 \\
Citrate 1-21 & 0.79 & 0.75 & 1.16 & 1.552 & 0 \\
Citrate 22-42 & 0.78 & 0.74 & 1.13 & 1.530 & 0.40 \\
Citrate 1-42 & 0.76 & 0.72 & 1.12 & 1.570 & 0.40 \\
Sulfate & 0.77 & 0.72 & 1.14 & 1.579 & 0.80 \\
\hline CV $(\%)$ & 2.30 & 2.40 & 2.00 & 3.60 & 1.60
\end{tabular}

$\mathrm{LW}=$ live weight; $\mathrm{WG}=$ weight gain; $\mathrm{FI}=$ feed intake; $\mathrm{FC}=$ feed conversion; MORT $=$ mortality + culling

Table 3 - Effects of cupric dietary citrate and cupric sulfate pentahydrate on performance of broiler chicken at age between 22 and 42 days.

\begin{tabular}{|c|c|c|c|c|}
\hline Treatment & WG & FI & $\mathrm{FC}$ & MORT \\
\hline & \multicolumn{2}{|c|}{$\ldots$} & $\mathrm{kg} \mathrm{kg}^{-1}$ & $\%$ \\
\hline Control & 1.65 & 3.25 & $1.969 \mathrm{ab}$ & 1.60 \\
\hline Citrate 1-21 & 1.65 & 3.32 & $2.011 \mathrm{ab}$ & 0.80 \\
\hline Citrate $22-42$ & 1.63 & 3.29 & $2.014 \mathrm{a}$ & 0.40 \\
\hline Citrate 1-42 & 1.68 & 3.31 & $1.973 \mathrm{ab}$ & 0.80 \\
\hline Sulfate & 1.65 & 3.25 & $1.967 \mathrm{~b}$ & 1.70 \\
\hline $\mathrm{CV}(\%)$ & 2.00 & 2.00 & 1.30 & 2.40 \\
\hline
\end{tabular}

${ }^{\mathrm{a}, \mathrm{b}}$ Values in the same column, followed by different letters, differ by Tukey test $(P<0.05)$.

$\mathrm{LW}=$ live weight; $\mathrm{WG}=$ weight gain; $\mathrm{FI}=$ feed intake; $\mathrm{FC}=$ feed conversion; MORT $=$ mortality + culling

Table 4 - Effects of dietary cupric citrate and cupric sulfate pentahydrate on performance of broiler chicken at age between 1 and 42 days.

\begin{tabular}{|c|c|c|c|c|c|}
\hline Treatment & LW $42 \mathrm{~d}$ & WG & FI & $\mathrm{FC}$ & MORT \\
\hline & - & $\mathrm{kg}-$ & -- & $\mathrm{kg} \mathrm{kg}^{-1}$ & $\%$ \\
\hline Control & 2.43 & 2.38 & 4.42 & 1.852 & 2.90 \\
\hline Citrate 1-21 & 2.44 & 2.40 & 4.48 & 1.868 & 0.80 \\
\hline Citrate $22-42$ & 2.42 & 2.38 & 4.43 & 1.863 & 0.80 \\
\hline Citrate 1-42 & 2.44 & 2.39 & 4.44 & 1.853 & 1.20 \\
\hline Sulfate & 2.42 & 2.38 & 4.39 & 1.849 & 2.50 \\
\hline C.V. (\%) & 1.80 & 1.80 & 1.40 & 1.40 & 2.70 \\
\hline
\end{tabular}

$\mathrm{LW}=$ live weight $\mathrm{WG}=$ weight gain; $\mathrm{FI}=$ feed intake; $\mathrm{FC}=$ feed conversion; MORT $=$ mortality + culling 
Pesti \& Bakalli (1996) confirmed the growth promoting effect of $\mathrm{Cu}$ in broiler chicken feed, and observed that cupric citrate was more efficient, at lower $\mathrm{Cu}$ levels, than cupric sulfate. The present work utilized the same cupric citrate $\left(75 \mathrm{mg} \mathrm{Cu} \mathrm{kg}^{-1}\right)$ and cupric sulfate $\left(200 \mathrm{mg} \mathrm{Cu} \mathrm{kg}^{-1}\right)$ levels for which the above authors obtained the best growth responses in their studies. However, no difference in response was observed between the sulfate and citrate forms. In two experiments, Ewing et al. (1998) observed increases in weight gain of $4.9 \%$ and $9.1 \%$ with cupric sulfate and citrate supplementation, respectively, and feed conversion was $5.2 \%$ and $7.6 \%$ better, when compared to the base diets.

The WG and FC results at 42 days for birds supplemented with cupric citrate in the present study (2.395 and $1.853 \mathrm{~kg}$, respectively) are similar to the results obtained by Pesti \& Bakalli (1996), with the same treatment (2.31 and $1.98 \mathrm{~kg}$, respectively). However, differences in WG and FC results of birds submitted to the Control treatment were observed in the present study ( 2.384 and $1.852 \mathrm{~kg}$, respectively), relative to the work by the previously mentioned authors $(2.15 \mathrm{~kg}$ and 2.05 , respectively). The Control birds in the present study, even though fed a base diet, without any growth promoter supplementation, attained a LW of $2.427 \mathrm{~kg}$ at 42 days, considered excellent for males of the utilized line. The lack of positive results for $\mathrm{Cu}$ action as a growth promoter in this study was, for the most part, attributed to the excellent performance attained by birds submitted to the Control treatment, which might be related to the sanitary conditions of the facilities during the conduction of the experiment.

Progressive weight gain and feed conversion rate increases can be observed when $\mathrm{Cu}$ is utilized in broiler chicken diet in successive trials. Johnson et al. (1985) tested the effect of $125 \mathrm{mg} \mathrm{Cu} \mathrm{kg}^{-1}$ (cupric sulfate) in broiler chicken diet on the performance and the concentration of this mineral in the litter, and its effects on the microflora in four successive trials carried out during a 12-month period, without changing the bedding. The authors did not find differences in bird growth and feed conversion efficiency for the first and second trials. However, in the third and fourth trials of the series, an increase in weight gain and feed conversion efficiency between 2 and 3\% was observed. The $\mathrm{Cu}$ concentrations in the litter of supplemented birds significantly increased to above $600 \mathrm{mg} \mathrm{Cu} \mathrm{kg}{ }^{-1}$ in the last trial. The concentration of fungi in the litter of supplemented birds progressively decreased as the trials were repeated. However, the bacterial counts in the litter was not affected by $\mathrm{Cu}$ supplementation. According to the authors, the lack of response of broiler chicken to supplementation with cupric sulfate in the first two trials of the se- ries suggests that the performance improvement in the last trials was caused by other nutritional or environmental factors, not by the antimicrobial activity of $\mathrm{Cu}$ in the diet. It is possible that the growth responses in the last trials of the study are related to gradual alterations in the condition of the litter, resulting from increasing $\mathrm{Cu}$ concentration and simultaneous reduction in the concentration of fungi. Further studies are needed to support this hypothesis.

It seems that conducting a single trial in which new bedding is utilized, under a controlled environment, to test the growth promoting effect of $\mathrm{Cu}$ is just not sufficient to obtain performance improvement results with supplemented birds. Since the present experiment consisted of a single assay, it is recommended that it should be repeated, given that the study by Pesti \& Bakalli (1996) consisted of a series of seven assays, to ensure a more reliable verification of the growth promoting action of $\mathrm{Cu}$ in broiler chicken diets.

There were differences $(P<0.01)$ between the $\mathrm{Cu}$ residue means in the litter of broiler chicken submitted to different treatments (Table 5). The $\mathrm{Cu}$ residues in treatments Control and Citrate 1-21 did not differ between themselves (43.2 and $54.7 \mathrm{mg} \mathrm{Cu} \mathrm{kg}^{-1}$, respectively). The same occurred with treatments Citrate 22-42 and Citrate 1-42 (97.7 and $115.2 \mathrm{mg} \mathrm{Cu} \mathrm{kg}^{-1}$, respectively). The highest $\mathrm{Cu}$ residue level $\left(197.2 \mathrm{mg} \mathrm{Cu} \mathrm{kg}^{-1}\right)$ was obtained with the utilization of cupric sulfate in the $\operatorname{diet}(P<0.01)$. The rice hulls sample collected before birds were housed had $24 \mathrm{mg} \mathrm{Cu} \mathrm{kg}^{-1}$.

RES results are in accordance to those found by Pesti \& Bakalli (1996), who observed that the use of cupric citrate in broiler chicken diet, for a 42-day period, produces lower $\mathrm{Cu}$ residues in the litter than when cupric sulfate is used, because of the lower levels of cupric citrate added to the feed. The use of cupric citrate as a replacement for cupric sulfate in diets results in the production of litter with a lower damage potential to the environment or to be used directly to feed ruminants (NRC, 1980).

Table 5 - Effect of treatments on litter $\mathrm{Cu}$ residues after rearing for 42 days.

\begin{tabular}{lc}
\hline Treatments & Cu Residue in litter \\
\hline & $\mathrm{mg} \mathrm{kg}^{-1}$ \\
Control & $43.2 \mathrm{c}$ \\
Citrate $1-21$ & $54.7 \mathrm{c}$ \\
Citrate $22-42$ & $97.7 \mathrm{~b}$ \\
Citrate $1-42$ & $115.2 \mathrm{~b}$ \\
Sulfate & $197.2 \mathrm{a}$ \\
\hline CV & 21.0 \\
a, b, c Values followed by different letters differ by Tukey test \\
$(P<0.01)$.
\end{tabular}




\section{ACKNOWLEDGEMENTS}

To FAPESP for financial support and to the Griffin Corporation, Valdosta, GA, USA, for the cupric citrate.

\section{REFERENCES}

BANTON, M.I.; NICHOLSON, S.S.; JOWET, P.L.H.; YEN, J.T. Copper toxicosis in cattle fed chicken litter. Journal of the American Veterinary Medical Association, v.91, p.827-828, 1987.

CROMWELL, G.L. Antimicrobial agents. In: MILLER, E.R.; ULLREY, D.E.; LEWIS, A.J. (Ed.) Swine nutrition. Stoneham:ButterworthHeinemann, 1991. cap.17, p.297-314.

EWING, H.P.; PESTI, G.M.; BAKALLI, R.I.; MENTEN, J.F.M. Studies on the feeding of cupric sulfate pentahydrate, cupric citrate and copper oxychloride to broiler chickens. Poultry Science, v.77, p.445-448, 1998.

FERNANDEZ, R.; LUCAS, E.; McGINNIS, J. Influence of diet composition on chick growth response to different antibiotics, feed additives and combination of the additives. Poultry Science, v.52, p.2299-2305, 1973.

FISHER, C.; LAURSEN-JONES, A.P.; HILL, K.J.; HARDY, W.S. The effect of copper sulphate on performance and the structure of the gizzard in broilers. British Poultry Science, v.14, p.55-68, 1973.

HILL, D.C.; BRANION, H.D.; SLINGER, S.J. Influence of environment on the growth response of chicks to penicillin. Poultry Science, v.32, p. $462-475,1953$.

HODA, A.A.; MAHA, M.H. Potency of copper as growth promoter in broiler chickens. Veterinary Medical Journal, v.43, p.77-85, 1995.

JOHNSON, E.L.; NICHOLSON, J.L.; DOERR, J.A. Effect of dietary copper on litter microbial population and broiler performance. British Poultry Science, v.26, p.171-177, 1985 .

KLASING, K.C.; LAURIN, D.E.; PENG, R.K.; FRY, D.M. Immunologically mediated growth depression in chicks: influence of feed intake, corticosterone and interleukin-1. Journal of Nutrition, v.117, p.1629$1637,1987$.
MARUSICH, W.L.; OGRINZ, E.E.; BROWN, P.R.; CLINE, T.R. Comparative efficacy of intermittent and continuous feeding of four antibiotics at low levels to broilers. Poultry Science, v.52, p.1771-1779, 1973.

NATIONAL RESEARCH COUNCIL. Mineral tolerance of domestic animals. Washington: National Academy of Sciences, 1980. 577p

PESTI, G.M.; BAKALLI, R.I. Studies on the feeding of cupric sulfate pentahidrate and cupric citrate to broiler chickens. Poultry Science, v.75, p.1086-1091, 1996.

POUPOULIS, C.; JENSEN, L.S. Effect of high dietary copper on gizzard integrity of the chick. Poultry Science, v.55, p.113-121, 1976.

ROSTAGNO, H.S.; SILVA, D.J.; COSTA, P.M.A.; FONSECA, J.B.; SOARES, P.R.; PEREIRA, J.A.A.; SILVA, M.A.; GOMES, P.C.; ALBINO, L.F.T. Composição de alimentos e exigências nutricionais de aves e suínos (Tabelas brasileiras). Viçosa: UFV, Imprensa Universitária, 1994. 59p.

ROURA, E.; HOMEDES, J.; KLASING, K.C. Prevention of immunologic stress contributes to the growth-permitting ability of dietary antibiotics in chicks. Journal of Nutrition, v.122, p.2383-2390, 1992.

RYSSEN, J.B.J. van; CHANNON, P.; STIELAU, W.J. Minerals and nitrogen in poultry manure. South African Journal of Animal Science, v.7, p.195-199, 1977.

SAS INSTITUTE. SAS procedures guide. Version 6. 3.ed. Cary:Statistical Analysis System Institute, 1990.

VISEK, W. J. The mode of growth promotion by antibiotics. Journal of Animal Science, v.46, p.1447-1469, 1978.

ZUANON, J.A.S. Efeito de promotores de crescimento sobre o desempenho de frangos de corte. Viçosa: UFV, 1995. 70p. (Dissertação - M.S.)

Received March 25, 2002

Accepted April 30, 2003 